\title{
The synergy of achievement, affiliation and powermotives on employee performance and commitment career as mediation: a literature examination
}

\author{
Agus Amperial ${ }^{1}$, Johanes ${ }^{2}$,Syahmardi Yacob $^{3}$, Shofia Amin ${ }^{4}$ \\ ${ }^{1)}$ Doctoral Program in Economics, Faculty of Economics and Business, Universitas Jambi, Indonesia, \\ ${ }^{2,3,4)}$ Faculty of Economics and Business, Universitas Jambi, Indonesia \\ Corresponding author: agusamperial1966@gmail.com
}

\begin{abstract}
Human behavior is influenced by three needs: achievement, affiliation, and power affiliation. In that regard, individual motivation encourages a person to achieve more results. Furthermore, employee performance is the output of an employee behavior process that refers to the achievement of performance and targets set by the organization, a reflection of the results achieved by an employee in the organization. Career commitment, in this case, plays an essential role because it becomes a longterm driver of the individual. This study intends to formulate a model of affiliation achievement motive and power motive on career commitment and employee performance where career commitment mediates. Thus, it could be a foundation for future research.
\end{abstract}

Keywords: Affiliate; Powermotives; Achievement; Commitment and Performance

\section{INTRODUCTION}

Performance is a crucial word for the sustainability of an organization, both profit and non-profit. Organizational planning, strategy formulation, organizational programs, and budgets achieve current performance and predetermined targets. Performance achievements from the output or work of employees will positively or negatively contribute to the organization. Employee performance reflects the results achieved by a person or group of people where there is a close relationship between individual performance or individual performance with institutional performance.

As previously mentioned, the low performance of an employee will impact organizational performance, or in other words, employee performance can reflect organizational performance. Etymologically, performance comes from the word performance (Susanty \& Baskoro, 2013). Performance is the result of a process (Suryadi, 2010). Therefore, performance is always measured from the aspect of results, not the efforts made by individuals, namely how well individuals can meet the demands of their work (Hosmani \& Shambhushankar, 2014).

According to some authors, some factors influence it, namely;

1) compensation, work environment, organizational culture, leadership, work motivation, work discipline, job satisfaction, communication, and other factors. (S. Akbar, 2018);

2) authority and Responsibility, discipline, initiative. (Sutrisno, 2009) from the journal (Daulay et al., 2019);

3) ability to adapt to environmental changes, according to (Bass et al., 2003) (Locander et al., 2002), is leadership (Shahzad, 2014). The results of this study prove that organizational culture has a positive 
and significant influence on the performance of employees or employees in the journal (Syafei et al., 2016);

4) Next, job satisfaction and work discipline affect employee performance. Hence, (Siagian 2002) mentioned Employee performance is influenced by several factors: compensation, training, work environment, work culture, leadership, motivation, discipline, job satisfaction (Sari \& Hadijah, 2016).

5) Other studies also found that various factors influence employee performance (Tria Meisya Aziti, 2013). He argued the influence of power, affiliation, and achievement on employee performance. They analyze the effect of Power, Affiliation, and achievement motivation on employee performance partially or simultaneously.

Accordingly, we note several previous research result as follow. Power motivation has a positive and significant effect; affiliate motivation has positive and substantial results instead of achievement motivation. The review of the research above shows that the factors that affect employee performance still show relevant results.

Furthermore, career commitment and those variables are rarely used to determine employee performance. It is essential for an employee because of its long-term nature, which encourages him to stay afloat and achieve more goals. It becomes our argument for determining the mediating variable and, at the same time, becomes the novelty of the study to be carried out.

Furthermore, our argumentation is supported by detail analyzing motivation. The factors affect employee performance; employees who do not have career commitments have little effect on performance. Research on performance is needed to improve employee performance. So the focus is on organizational goals. Zulfitri (2016) examine to determine the direct influence of the need for achievement, affiliation, and power on employees' ability the direct result of employee abilities on employee performance. The condition for achievement affiliation directly affects employee ability, and the Need for Power does not directly affect the organization's performance.

Furthermore, we consider career commitment as another main factor that affects performance indirectly. Career commitment is why an employee is involved in all organizational problems to achieve organizational goals. According to previous research, achievement, power, and affiliation significantly affect employee performance. The analysis results show that the need for achievement, power, and affiliation positively affect employee performance.

Furthermore (Hernanda, 2018) showed a positive relationship between the need for achievement, the need for power, and relevance for further research. Accordingly, it is argumentative to consider career commitment as another variable to influence employee performance. Someone who has a career commitment will love his employees more, and the results of his employees are better. The findings of this study support the results of research (van der Heijden et al., 2009) where if the company/organization does not help an employee (expatriate) whose career planning, will be very vulnerable to move to another organization.

That argumentation is supported by (Wiener \& Vardi, 1980). He argues that a committed career is the best predictor of employee performance. In line with the organization's HR needs, good career planning will make an employee stay in the company for a long time. Employees who have only worked for a few years and employees who have worked for decades in the organization certainly have different levels of commitment and will provide different levels of performance (Febriansah, 2016).

Based on Febriansah (2016), there is a mediating relationship between career commitment to employee performance. Hence, we could consider career commitment as an antecedent of employee performance. Furthermore, it is reasonable to say career commitment could be a mediating variable.

Based on previous research explorations, a few researchers considered career commitment as their observation. However, this study integrated it with achievement motives, affiliation motives, and power motives still rarely practiced. In doing so, we will find research novelty in future research. So 
the purpose of this study is to reveal the relationship between achievement motives, affiliation motives, and power on employee performance mediated or intervened by career commitment. It could be a model for future research as the initial research.

\section{LITERATURE REVIEW}

\section{- Motivation Theory Concept.}

Based on McClelland's motivational needs theory, there are three kinds of determinants, namely the need for achievement or achievement, power, and affiliation. The need for achievement, power, and affiliation building in the pioneering research Harvard Psychological Clinic. Murray (1938) first discussed the importance of the need for achievement, the Need for Power, and affiliation in the integrated motivation model. McClelland (1988) later published the Achieving Society, in which he proposed that these three needs form the basis of human motivation in the work environment. McClelland categorizes three conditions in a person that can motivate work passion, namely:

1) The need for achievement, namely, achievement, reflects the drive for problem responsibility for problem-solving.

2) The need for affiliation, namely the need for cooperation, is an urge to interact with other people, be with other people, do not want to do something that harms others.

3) Need for power, namely the need for control, reflects the drive to achieve authority to influence others.

Tria Meisya Azizi (2013) argued that the three determinants are still relevant for employee performance determination. Yamit (2005) reports that the achievement motive, affiliation motive, and power motive in this study can explain a positive and significant effect on the performance of BRI employees in the Branch Office. Achievement motive has a positive impact but is not effective on the performance of BRI Sleman Branch employees. Achievement Needs Variables. This test shows that the achievement Needs variable has no significant effect on the Employee Performance variable. When referring to the data on the frequency distribution of the achievement needs variable, this can occur because the influence of the item can develop ideas at work and have the ability to create self-potential, which has the lowest mean value.

Affiliation Needs Variable This test shows that the affiliation Needs variable has no significant effect on employee performance. When referring to the frequency distribution data for the variable need for affiliation, this can occur because the impact of the item has a high and collaborative level of cooperation in doing work that has the lowest mean value (Dany \& Mayowan, 2015)

McClelland's Theory of Needs - McClelland's theory of needs is one motivational theory that states three needs: achievement or achievement, the Need for Power, and the Need for will affiliate. The need for achievement, the need for control, and the Need for Affiliation Building in the pioneering research Harvard Psychological Clinic (Murray, 1938) first discussed the importance of Need for Achievement, the Need for Power, and the Need for Affiliation in the context of an integrated motivational model. (McClelland, 1988) later published The Achieving Society, in which he proposed that these three needs form the basis of human motivation in the environment. The idea, also known as Needs Theory and learned needs theory, is how the three needs (Need for Achievement, Power, and Affiliation) can influence people's actions in a work context. McClelland grouped three conditions in a person that can motivate, passion for work, which is still relevant and supports the theory in the author's research.

\section{- Career Commitment.}

The concept of career commitment was first introduced by (Hall 1971) as the strength of an individual's motivation to work in his chosen career. Career commitment is related to individual career 
growth, namely in the form of increasing competence and personal characteristics that are relevant to their career roles. When individuals become more competent and successful in their chosen career, the satisfaction obtained by the individual will increase the individual's commitment to his career choice. The study of the concept of career commitment is growing from time to time. The results show that work-family balance has a positive relationship with personal career success, a work-family balance has a positive relationship with career commitment. Next, career commitment has a positive relationship with career success, and career commitment partially mediates the relationship between work-family balance and success. Subjective career (S.amin, nd) Employees with the highest organizational commitment are committed to their careers and remain in the organization. The belief in and acceptance of goals and values in the organization keeps them inspired, satisfied, and committed to a job. Self-efficacy significantly affects career commitment (Susan et al., 2012). From the analysis result, it is found that emotional intelligence involves career commitment. Meanwhile, work value and work-life balance do not affect career commitment. Meanwhile, work values and work-life balance have no impact on career commitment (Kristanto, 2016). Career satisfaction positively affects career success through career commitment, and It is shown in the t-statistic value of $2.212>1.96$ and the original sample value of 0.438 . Career commitment is an intervening variable of career satisfaction on career success (Amiruddin, 2019). Career commitment and personal career success can predict readiness to face change, either together (simultaneously) or individually. Still, influence will be more substantial if career commitment interacts simultaneously with personal career success than the power of persuasion individually.

Work-family balance was found to mediate the relationship between partner support and personal career success. In contrast, career commitment was found to mediate work-family credit and individuals. Accordingly, Table shows several career commitments.

Table 1. Some definitions of career commitment

\begin{tabular}{|c|c|c|}
\hline NO & Definition & Source \\
\hline 1 & $\begin{array}{l}\text { Career commitment is the strength of an individual's motivation } \\
\text { to fulfill the chosen career role }\end{array}$ & (Hall, 1971) \\
\hline 2 & $\begin{array}{l}\text { Career commitment is the identification and involvement of } \\
\text { individuals in a profession. }\end{array}$ & $\begin{array}{l}\text { (Morrow \& } \\
\text { Wirth, 1989) }\end{array}$ \\
\hline 3 & $\begin{array}{l}\text { Career commitment is defined as the stability and continuation of } \\
\text { one's job }\end{array}$ & $\begin{array}{l}\text { (Van Maanen, } \\
\text { John Eastin and } \\
\text { Schein, 1977) }\end{array}$ \\
\hline 4 & $\begin{array}{l}\text { Career commitment is an individual's attitude towards his job or } \\
\text { profession }\end{array}$ & (Blau, 1989) \\
\hline 5 & $\begin{array}{l}\text { Career commitment is an attitude towards an individual's career } \\
\text { or as an individual's psychological response to a professional } \\
\text { career }\end{array}$ & $\begin{array}{l}\text { (Arthur et al., } \\
\text { 1989) }\end{array}$ \\
\hline 6 & $\begin{array}{l}\text { Career commitment is the behavior of setting individual career } \\
\text { goals and the integration and identification of these goals with the } \\
\text { individual }\end{array}$ & $\begin{array}{ll}\text { Colarelli } & \& \\
\text { Bishop, 1990) } & \end{array}$ \\
\hline 7 & $\begin{array}{l}\text { Career commitment is a person's identification and involvement } \\
\text { with his work }\end{array}$ & $\begin{array}{l}\text { (MUELLER et } \\
\text { al., 1992) }\end{array}$ \\
\hline 8 & $\begin{array}{l}\text { Career commitment is a sign that shows an individual's effort to } \\
\text { achieve his career goals. }\end{array}$ & $\begin{array}{l}\text { (Ellemers et al., } \\
1998)\end{array}$ \\
\hline 9 & $\begin{array}{l}\text { Career commitment is the extent to which a person identifies the } \\
\text { value of the profession, the work, the amount of time and effort } \\
\text { devoted to acquiring relevant knowledge }\end{array}$ & $\begin{array}{l}\text { (Goulet \& Singh, } \\
\text { 2002) }\end{array}$ \\
\hline 10 & $\begin{array}{l}\text { Career commitment is an essential factor that helps individuals } \\
\text { stay in a particular job long enough to develop specific skills. }\end{array}$ & (Niu, 2010) \\
\hline
\end{tabular}


To achieve the desired career, employees must work diligently and consider career advancement as a goal that must be completed. In carrying out career development, employees are expected to find or explore hidden abilities. Employee performance. Some expert opinion on performance. Performance is the result achieved by a person according to the size applicable to the job in question (Sutrischastini \& Riyanto, 2017). The performance or work performance results from an employee's work over a certain period compared to the possibilities, for example, standards, targets or targets, or performance that have been determined in advance and have been mutually agreed upon. The results of performance appraisals, both stating the weaknesses or shortcomings of employees and their achievements or successes, are precious information for leaders. (Yulianti, 2017)

According to (Brahmasari 2004), employee performance is an action taken by employees to complete the tasks for which they are responsible within a certain period and can be measured through quantity, quality, duration, and level of attendance and cooperation. According to (Richardson et al., 1989), performance is a behavior in carrying out tasks by its role in the company. Performance appraisal is based on achieving targets over a specific period. Based on the above explanation, we argued that employee performance is an action taken by employees to complete the tasks for which they are responsible according to their roles within a certain period and can be measured based on quantity, quality, period, level of attendance, and cooperation (Rifky et al., 2017).

\section{DISCUSSION}

\section{Motives of Achievement, Affiliation, and Power towards career commitment}

Based on the previous explanation, we argue that achievement motives, affiliation, and power with career commitment, affect employee performance. For example, if an honorarium teacher is dismissed from where he teaches, he works elsewhere and remains a teacher. $\mathrm{He}$ remains committed to his career as a teacher, which is considered a calling. Based on the needs theory approach, it is stated that an integrated model of the three needs drives in a person (motive) is the basis of human motivation in the work environment. The theory of markets refers to a professional relationship or a person's professional work because it is a soul calling. He feels he has a high sense of responsibility, and perhaps because of the expertise or scientific aspects, his profession is a commitment to his career.

Career commitment is a strength of an individual's motivation to fulfill a chosen career role (Hall, 1971). Conceptually, Hall (in (Cohen, 1996)) uses a career approach to define career commitment as the amount of individual motivation to work and have a career in the chosen job or profession. Career commitment is an attitude towards an individual's employment or as an individual's psychological response to a professional career (E. et al. Arthur, 1989). Career commitment is individuals in a profession's motivation, attitude, and behavior to live and survive in their chosen career role (Ingarianti et al., 2019).

\section{Achievement motives, Affiliation, and Power on performance}

People love each other, both in terms of their ability and willingness to do something differently. Employees or employees who have motivation will be their driving force to get work results (performance). The encouragement of needs in a person in the form of a motive for achievement, cooperation, and a reason for gaining power is an action to produce performance. Employees or employees who have high work motivation will positively impact the organization to achieve organizational goals. 
The need for achievement affects workers' ability, the need for cooperation affects workers' knowledge, and the Need for Power does not affect workers' ability but affects performance. The study results through statistical testing showed that power motivation had positive and significant results, affiliate motivation had positive and substantial results, but achievement motivation was not crucial on performance (Tria Meisya Aziti, 2013).

The analysis results show that the variables need for achievement, need for power, and affiliation positively affect employee performance variables. Each variable also affects increasing and decreasing employee performance variables. Therefore, if the variables need for achievement, need for power, and need for affiliation are used simultaneously or simultaneously, it can significantly affect employee performance variables (Hernanda, 2018).

\section{Career commitment}

Someone who has a career commitment will work wholeheartedly and thoughtfully to improve performance. In addition, someone who has a career commitment is more loyal to the workers loves his job more so that performance increases more than people who do not have a career commitment. Aspects of loyalty to the profession, work wholeheartedly and consider it a calling from the soul, the impact of one's career commitment can positively contribute to the organization.

Career commitment has a strategic role for individuals and organizations. Various research showed the positive influence of career commitment on performance, including research (Lee \& Schofield, 2000) which states that employees who have a high career commitment will be engaged in work and achieve higher performance than employees who have a high career commitment. It is supported by (Aryee \& Tan, 1992), who said that employees who are highly committed to their careers would use time and resources to improve skills and have a low desire to leave their jobs. Employees with high career commitment will try to understand the organization's needs, and they will make adjustments proactively so that their personal goals are aligned with organizational goals (Ding et al., 2017).

The term career commitment is often referred to as occupational commitment or professional commitment. These terms have subtle differences in meaning, so they are often used interchangeably. Career commitment is different from organizational commitment, and an employee may be committed to his job but not to his career. Individuals committed to their careers are more focused on their careers than working conditions and colleagues, and even the organization they work for. When individuals experience high dissatisfaction with the organization, they may continue working because of career considerations. Individuals with high career commitment tend to be motivated by their career expectations and goals (Wright \& Jones, 2006).

According to (Ingarianti et al., 2019), career commitment is an attitude of a person or individual in achieving the desired career goals. According to (Ahmed 2017), employees who have a career commitment will be motivated to complete work, perform well in their careers, and help the organization be successful. Someone who cares about his career tends to be committed to his career. Career commitment is a person's belief and acceptance of the value of the job he has chosen and the desire to stay at his job.

According to Damayanti (2017), Work-Life Balance is also included in the aspects of Career Commitment. The number of workers who change their careers causes these workers not to reach the peak of their careers. At the same time, workers should have a career commitment because career commitment is an essential factor to survive in a specific job for a long time to develop the unique skills possessed by the individual (Niu, 2010). According to (Wesarat et al., 2014), career commitment is an essential concept for employees, considering it helps align 
employee careers with changing conditions that occur within the company. The work value of the attitude attached to a career that can be felt in the individual certainly wants a better career in every job to get an award and achievement that has been carried out (Amiruddin, 2019).

\section{Motives of Achievement, Affiliation, and Power on performance with career commitment as mediation}

The positions of the intervening variables or career commitment variables are: (1) Indirectly influenced by the three motive variables, which at the top of the article (2.2.1) have shown a meaningful relationship; (2) Indirectly influencing individual performance variables which at the top of this article (2.2.3) have shown a meaningful relationship; (3) the influence of the three motive variables on individual performance variables must be indirectly related to the intervening/mediation variable, namely career commitment.

Career commitment as a mediating variable is influenced indirectly by the three motive variables, and career commitment indirectly affects employee performance variables. Many things support human resources to have good quality and performance, one of which is the employees' commitment to the company. Organizational commitment encourages employees to keep their jobs and show the results they should. Employees who have a high responsibility to the company tend to offer good quality, more totality at work, and the turnover rate for the company is low. The variables of affective commitment, continuity commitment, and normative commitment together (simultaneously) have a positive and significant effect on employee performance. Affective and normative commitment (partial) have a positive and significant impact. Still, the independent variable continuity commitment partially has a positive and insignificant effect on employee performance (A. Akbar et al., 2017). The authors study that the research (A. Akbar et al., 2017) is different from the author's research plan, where the author's research highlights that employee performance is influenced by career commitment.

Organizational commitment is the attitude of employees to remain in the organization and be involved in efforts to achieve the organization's mission, values, and goals. According to (Meutia \& Husadha, 2019), high employee organizational commitment will make employees work more optimally, and the performance generated by employees will also increase positively. Meanwhile, according to (NingTyas, Azisah Putri Ayu and Purnomo, Suseno Hadi, and Aswar, 2020), organizational commitment is essential because it will impact employee performance in carrying out their duties and responsibilities. This study shows that commitment to employee performance has a positive and significant effect. Meanwhile, turnover intention negatively affects employee performance and is not substantial (Jamal et al., 2021). A review of research (Jamal et al., 2021) shows that the results of his research are very relevant. It is proven that turnover hurts employees who are committed to the organization. So the authors provide confidence that the impact will be the same between using the variable career commitment or organizational commitment. Employees who have a career commitment will be motivated to get work done, perform well in their careers, and help the organization to be successful. Someone who cares about his career tends to be committed to his career.

Career commitment also affects readiness to face the changes (Fridayanti 2018). The results of his study show that career commitment and career success, both individually and collectively, affect readiness to face change. 


\section{Logical Construction}

Logical construction of the future research is described as follows below based on the support of a brief conceptual model of individual performance as follows:

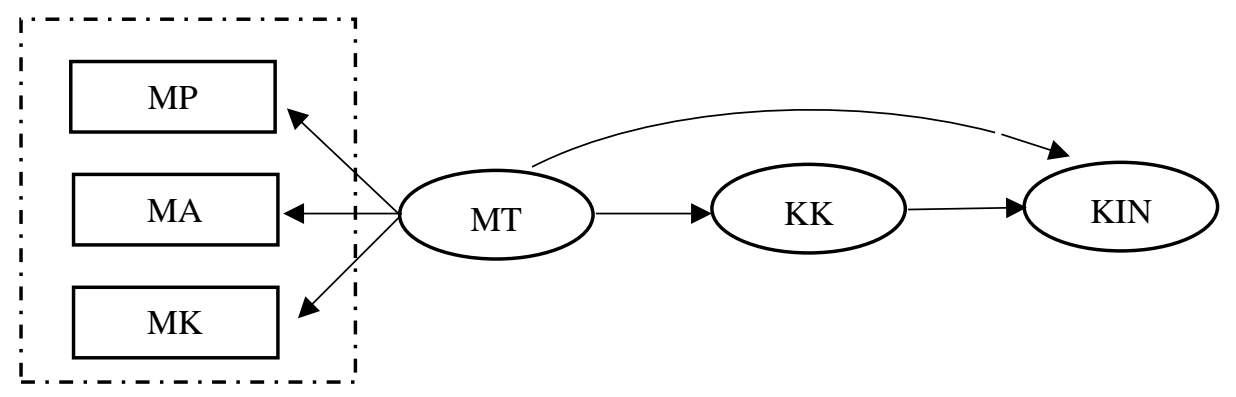

Figure 1. Logical Construct

Description: $\mathrm{MT}=$ Motive, $\mathrm{KK}=$ Career Commitment, $\mathrm{KIN}=$ Individual Performance, $\mathrm{MP}=$ Achievement Motive, $\mathrm{MA}=$ Affiliation Motive, $\mathrm{MK}=$ Power Motive .

\section{Hypothesis}

Based on the study of theory, framework, and research paradigm, the following idea is proposed:

$\mathrm{H}_{1}$ : Motives have a positive and significant influence on career commitment.

$\mathrm{H}_{2}$ : Motives have a positive and significant impact on employee performance.

$\mathrm{H}_{3}$ : Commitment has a positive and significant effect on employee performance.

$\mathrm{H}_{4}$ : Motives have a positive and significant influence on performance through career commitment

\section{REFERENCES}

Arthur, B., Hall, T., \& Lawrence, S. (1989). Handbook of Career Theory. Cambridge University Press.

Blau, G. (1989). Testing the generalizability of a career commitment measure and its impact on employee turnover. Journal of Vocational Behavior. https://doi.org/10.1016/00018791(89)90050-X

Colarelli, S. M., \& Bishop, R. C. (1990). Career Commitment: Functions, Correlates, and Management. Group \& Organization Studies, 15(2), 158-176. https://doi.org/10.1177/105960119001500203

Ellemers, N., De Gilder, D., \& Van Den Heuvel, H. (1998). Career-Oriented Versus Team-Oriented Commitment and Behavior at Work. Journal of Applied Psychology. https://doi.org/10.1037/0021-9010.83.5.717

Goulet, L. R., \& Singh, P. (2002). Career Commitment: A Reexamination and an Extension. Journal of Vocational Behavior, 61(1), 73-91. https://doi.org/10.1006/jvbe.2001.1844

Hall, D. T. (1971). A theoretical model of career subidentity development in organizational settings. Organizational Behavior and Human Performance, 6(1), 50-76. https://doi.org/10.1016/00305073(71)90005-5

Morrow, P. C., \& Wirth, R. E. (1989). Work commitment among salaried professionals. Journal of Vocational Behavior. https://doi.org/10.1016/0001-8791(89)90063-8

Mueller, C. W., Wallace, J. E., \& Price, J. L. (1992). Employee Commitment: Resolving some Issues. 
Work and Occupations, 19(3), 211-236. https://doi.org/10.1177/0730888492019003001

Niu, H.-J. (2010). Investigating the effects of self-efficacy on foodservice industry employees' career commitment. International Journal of Hospitality Management, 29(4), 743-750. https://doi.org/10.1016/j.ijhm.2010.03.006

Van Maanen, John Eastin and Schein, E. H. (1977). Toward a theory of organizational socialization. MIT Alfred P. Sloan School of Management.

Arthur, B., Hall, T., \& Lawrence, S. (1989). Handbook of Career Theory. Cambridge University Press.

Blau, G. (1989). Testing the generalizability of a career commitment measure and its impact on employee turnover. Journal of Vocational Behavior. https://doi.org/10.1016/00018791(89)90050-X

Colarelli, S. M., \& Bishop, R. C. (1990). Career Commitment: Functions, Correlates, and Management. Group \& Organization Studies, 15(2), 158-176. https://doi.org/10.1177/105960119001500203

Ellemers, N., De Gilder, D., \& Van Den Heuvel, H. (1998). Career-Oriented Versus Team-Oriented Commitment and Behavior at Work. Journal of Applied Psychology. https://doi.org/10.1037/0021-9010.83.5.717

Goulet, L. R., \& Singh, P. (2002). Career Commitment: A Reexamination and an Extension. Journal of Vocational Behavior, 61(1), 73-91. https://doi.org/10.1006/jvbe.2001.1844

Hall, D. T. (1971). A theoretical model of career subidentity development in organizational settings. Organizational Behavior and Human Performance, 6(1), 50-76. https://doi.org/10.1016/00305073(71)90005-5

Morrow, P. C., \& Wirth, R. E. (1989). Work commitment among salaried professionals. Journal of Vocational Behavior. https://doi.org/10.1016/0001-8791(89)90063-8

Niu, H.-J. (2010). Investigating the effects of self-efficacy on foodservice industry employees' career commitment. International Journal of Hospitality Management, 29(4), 743-750. https://doi.org/10.1016/j.ijhm.2010.03.006

Van Maanen, John Eastin and Schein, E. H. (1977). Toward a theory of organizational socialization. MIT Alfred P. Sloan School of Management. 